\title{
Diagnostic value of serum haptoglobin
}

\author{
N. K. SHINTON, R. W. RICHARDSON, AND J. D. F. WILLIAMS \\ From Coventry and Warwickshire Hospital, Coventry
}

SYNOPSIS Serum haptoglobin has been estimated quantitatively in 25 patients with haemolytic disease, and its diagnostic value assessed by comparing the levels with those obtained in 110normas subjects, in 149 patients with other forms of anaemia, and in 37 patients with non-haematologicad disorders. The normal range was found to be 33 to $213 \mathrm{mg}$./100 ml.; subnormal levels were found ih $80 \%$ of patients with haemolytic disease or megaloblastic anaemia, patients with haemorrhage into the tissues, and occasionally in association with other diseases. When taken in conjunction with other clinical and laboratory features this simple biochemical estimation can be of diagnostic value.

Haptoglobins are a group of serum proteins, originally identified by Polonovski and Jayle (1939), which have the characteristic property of combining with haemoglobin to form a stable complex. Quantitative estimation of haptoglobins depends upon measuring the amount of this haemoglobinhaptoglobin complex formed when the test serum has been allowed to combine with free haemoglobin either as oxyhaemoglobin or methaemoglobin and is therefore a measure of their haemoglobin-binding capacity.

Neale, Aber, and Northam (1958) showed that in patients with excessive haemolysis clearance of haemoglobin from serum leads to absence or reduction of haptoglobins. Serum haptoglobin estimation may therefore be of value in the diagnosis of haemolytic disease (Nosslin and Nyman, 1958) but clinical interpretation is difficult because of low levels occurring in some normal subjects (Table I). Furthermore, Allison, Blumberg, and ap Rees (1958) found a complete absence of serum haptoglobins in $2 \%$ of normal healthy British subjects and in $30 \%$ of healthy Nigerian subjects. It has also been recognized that decreased levels are found in association with hepatocellular disease (Nyman, 1959; Owen, Mackay, and Got, 1959; Williams, Speyer, and Billing, 1961). Raised levels have been found in serum from patients with infection, malignancy, connective tissue disorder, biliary obstruction, glomerulonephritis, pyelonephritis, ulcerative colitis, arterial disease, acute rheumatic fever, myocardial infarction (Owen, Smith, Padanyi, and Martin, 1964), and haemoblastoses (Iványi, Sochman, and Iványi, 1961). Both high and low levels occur in patients receiving steroid therapy (Brus and Lewis,

Received for publication 31 March 1964.
1959; Borglin and Nyman, 1961). Doubt has therem fore been thrown on the diagnostic value of this estimation, and so we have assessed its use in the investigation of patients with haemolytic disease and compared their levels with those from normag subjects, patients with other forms of anaemia, and patients with non-haematological disorders.

\section{TABLE I}

SERUM HAPTOGLOBIN LEVELS IN NORMAL SUBJECTS

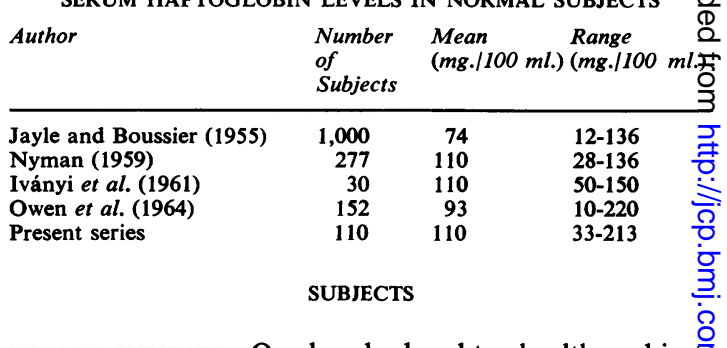

NORMAL SUBJECTS One hundred and ten healthy subjects volunteered, 14 being laboratory staff, 81 blood donors and 14 old age pensioners.

PATIENTS Two hundred and fifteen cases are groupe into the following categories:-

Haemolytic disease Twenty-five cases with a normocytic normochromic anaemia associated with reticulos cytosis, erythroblastaemia, and such features as splenof megaly, microspherocytosis, elliptocytosis, auto-immune red cell antibodies, increased red cell osmotic fragilit abnormal haemoglobin, decreased red cell survival: ne् all of the cases had overt anaemia at the time the estof mation was made.

Megaloblastic anaemia Thirty-three cases with megalo blastic erythropoiesis: this group included patients wif pernicious anaemia, post-gastrectomy vitamin $\mathbf{B}_{\mathbf{R}}^{\mathbb{T}}$ deficiency, intestinal malabsorption, and anaem following treatment with anticonvulsant drugs. 
Iron-deficiency anaemia This category comprises 65 cases with hypochromic anaemia and mean cell haemoglobin concentration below $32 \%$. In those cases where the serum iron and iron-binding capacity was determined it was found to be outside the normal ranges for the respective age and sex of the particular patient. Anaemia was due either to chronic haemorrhage, nutritional iron deficiency, or intestinal malabsorption.

Recent haemorrhage Twenty-eight cases of normocytic normochromic anaemia following recent blood loss from the gastro-intestinal tract, nose or uterus, or from bleeding into the tissues as a result of trauma, coagulation defect, or vascular disorder.

Reticulosis Twenty cases in which the diagnosis was either acute leukaemia, myeloid leukaemia, myelofibrosis, lymphatic laekaemia, lymphosarcoma, reticulum-cell sarcoma, or Hodgkin's disease.

Miscellaneous anaemias Three cases of 'hypersplenism', one of which was secondary to hepatic cirrhosis, two cases of aplastic anaemia, and two of sideroblastic, anaemia.

Other diseases Thirty-seven cases with a nonhaematological disorder: this group included patients with conditions such as bronchitis, pneumonia, HammonRich syndrome, subacute bacterial endocarditis, pyelonephritis, pyogenic abscess, cholecystitis, hepatitis, hepatic cirrhosis, pancreatitis, hypothyroidism, rheumatoid arthritis, benign or malignant tumours.

\section{METHODS}

Serum haptoglobin was measured by the method of Owen, Better, and Hoban (1960). Here the peroxidase activity of the haemoglobin-haptoglobin complex obtained when haptoglobin is bound by methaemoglobin is measured by the colour developed when added to hydrogen peroxide and guaicol. This technique measures the total serum haptoglobin and makes no attempt to differentiate between the types of haptoglobin demonstrated by starch gel electrophoresis (Smithies, 1955). Quantitative estimation was made up to $250 \mathrm{mg}$./100 ml., but where the level was in excess of this concentration it was recorded as greater than $250 \mathrm{mg} . / 100 \mathrm{ml}$.

In 19 selected cases red cell survival was determined by the radioactive chromium technique (Veall and Vetter, 1958), the patients' own cells being labelled by ${ }^{51} \mathrm{Cr}$, washed in saline, and later reinjected. Blood samples were taken after 15 minutes, 24 hours, 48 hours, and then at three-day intervals until the ${ }^{51} \mathrm{Cr}$ half-life had been passed. The results were expressed in terms of half-time for the disappearance of ${ }^{51} \mathrm{Cr}$ from the circulation $\left(\mathrm{T} \frac{1}{2}{ }^{51} \mathrm{Cr}\right.$ ), without correction for chromium elution. Due to uncertainties with regard to the activities of some of the 15 -minute specimens, the $100 \%$ value was taken as the activity found after 24 hours. The mean $\mathrm{T}_{2}{ }^{51} \mathrm{Cr}$ by this method is 25.5 days. In later studies the labelled red cells were washed in a phosphate-citrate buffer, as recommended by Mollison (1961). This procedure decreases the elution of chromium and prolongs the $\mathrm{T} \frac{1}{2}{ }^{51} \mathrm{Cr}$ to 32.5 days (range $28-33$ days).

Haemoglobin, serum bilirubin, and other haematological data were obtained by methods described by Dacie and Lewis (1963).

\section{RESULTS}

The serum haptoglobin levels have been charted according to their respective clinical groups (Fig. 1).

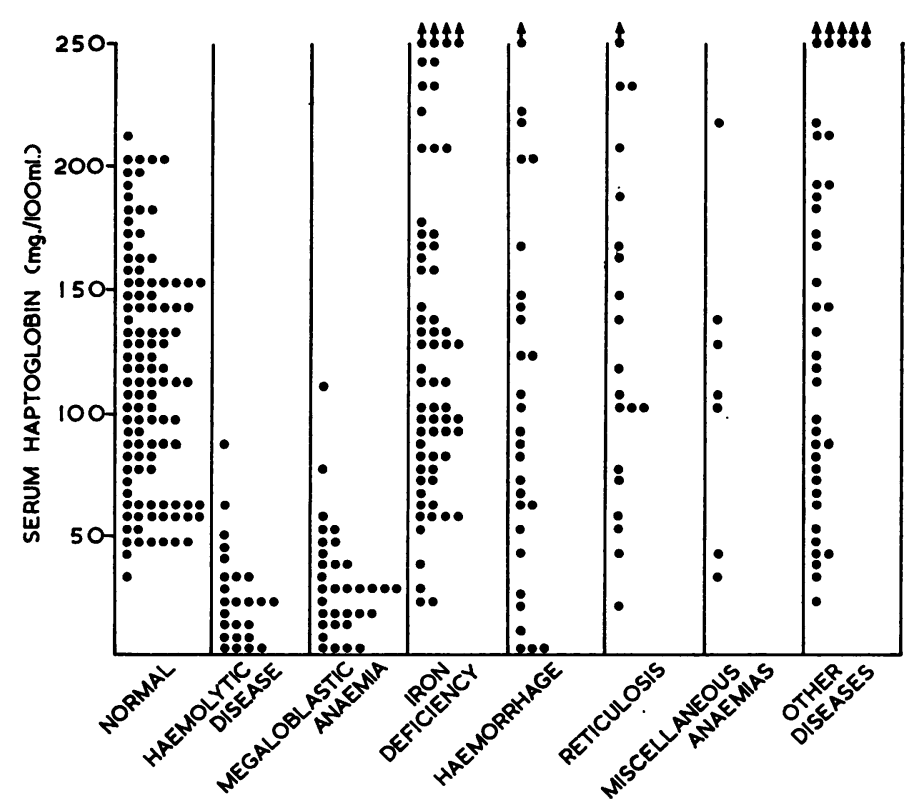

FIG. 1. Levels of serum haptoglobin in normal subjects and different clinical groups. 


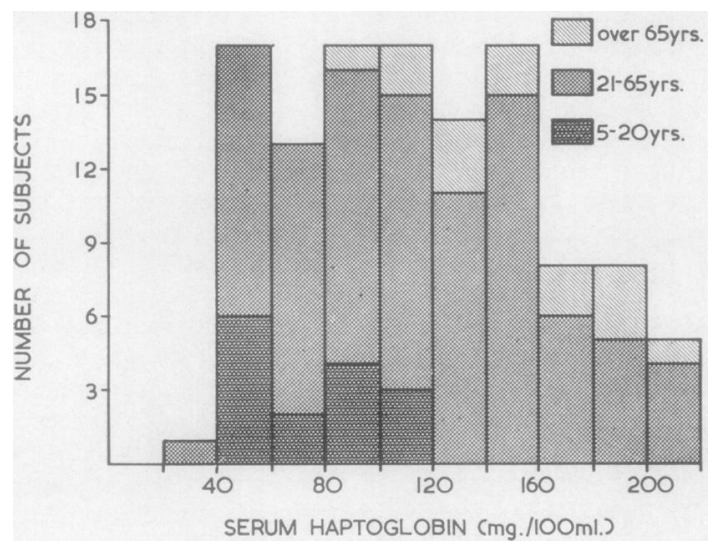

FIG. 2. Distribution of serum haptoglobin levels in 110 normal subjects.

NORMAL SUBJECTS In 54 males the serum haptoglobin range was $40-213 \mathrm{mg} . / 100 \mathrm{ml}$. (mean 108 $\mathrm{mg} . / 100 \mathrm{ml}$.) and in 56 females $33-190 \mathrm{mg} . / 100 \mathrm{ml}$. (mean $111 \mathrm{mg} . / 100 \mathrm{ml}$.). The mean for both sexes was $110 \mathrm{mg} . / 100 \mathrm{ml}$. The distribution showed a positive skew curve (Fig. 2). In only one subject was the level below $40 \mathrm{mg}$. $/ 100 \mathrm{ml}$. so this has been taken as an arbitrary lower limit of normal in this investigation. None of the 14 subjects under 20 years of age had a level above $120 \mathrm{mg} . / 100 \mathrm{ml}$. and none of the 14 subjects over 65 years of age had a level below $80 \mathrm{mg} . / 100 \mathrm{ml}$. Apart from this suggestion of an increase in level with age it was not possible t demonstrate a change with age for the whole series

HAEMOLYTIC DISEASE The range of serum haptog globin varied from 0 to $85 \mathrm{mg}$./100 ml. (Table II) Of the 25 patients investigated, 14 had levels of $20 \mathrm{mg} . / 100 \mathrm{ml}$. or below, while four were abov\& $40 \mathrm{mg} . / 100 \mathrm{ml}$., cases 5,14 , and 19 having marked anaemia with reticulocytosis and raised levels of. unconjugated bilirubin, while case 12 had a decrease $\mathbb{P}$ red cell survival time. In the group as a whole, there was little correlation between serum haptoglobio and bilirubin levels, the latter being within norma limits in eight of the 25 cases, all of which had low levels of haptoglobin, five with marked anaemia. There was little general correlation between the levels of serum haptoglobin and the haemoglobia concentration.

MEgALOBLASTIC ANAEMIA The range in the 33 cases was $0-110 \mathrm{mg} . / 100 \mathrm{ml}$., 13 having levels below $20 \mathrm{mg} . / 100 \mathrm{ml}$. and eight above $40 \mathrm{mg} . / 100 \mathrm{ml}$. Thఖ patient with a level of $110 \mathrm{mg} . / 100 \mathrm{ml}$. had haemoglobin concentration of only $6.6 \mathrm{~g} . / 100 \mathrm{ml}$ but also suffered from pyelonephritis. The one with \& level of $75 \mathrm{mg} . / 100 \mathrm{ml}$. had classical pernicious anaemia of mild degree (haemoglobin $10.5 \mathrm{~g}$. $/ 10$ \% ml.).

IRON-DEFICIENCY ANAEMIA In the 65 cases of this group the range varied from 20 to over $250 \mathrm{mg}$ $100 \mathrm{ml}$. The patient (case 26) with the level of $2 \mathrm{~g}$

TABLE II

SERUM HAPTOGLOBIN, BILIRUBIN, AND HAEMOGLOBIN LEVELS IN 25 CASES OF HAEMOLYTIC ANAEMIA

\begin{tabular}{|c|c|c|c|c|}
\hline Case & Diagnosis & $\begin{array}{l}\text { Serum Haptoglobin } \\
(\mathrm{mg} . / 100 \mathrm{ml} .)\end{array}$ & $\begin{array}{l}\text { Serum Bilirubin } \\
(\mathrm{mg} . / 100 \mathrm{ml} .)\end{array}$ & Haemoglobin $(\mathrm{g} . / 100 \mathrm{ml})$. \\
\hline 1 & Hereditary spherocytosis & 10 & $1 \cdot 1$ & $10 \cdot 4$ \\
\hline 2 & Hereditary spherocytosis & 24 & $3 \cdot 4$ & $12 \cdot 0$ \\
\hline 3 & Hereditary spherocytosis & 20 & $2 \cdot 5$ & $12 \cdot 4$ \\
\hline 4 & Hereditary spherocytosis & 0 & $3 \cdot 0$ & $9 \cdot 7$ \\
\hline 5 & Hereditary spherocytosis & 62 & $1 \cdot 3$ & $8 \cdot 0$ \\
\hline 6 & Hereditary spherocytosis & 18 & 0.8 & $14 \cdot 9$ \\
\hline 7 & Hereditary spherocytosis & 12 & $2 \cdot 5$ & $8 \cdot 2$ \\
\hline 8 & Hereditary spherocytosis & 33 & 1.0 & $10 \cdot 0$ \\
\hline 9 & Hereditary spherocytosis & 40 & 0.6 & $14 \cdot 6$ \\
\hline 10 & Hereditary elliptocytosis & 20 & $1 \cdot 0$ & $12 \cdot 0$ \\
\hline 11 & Hereditary elliptocytosis & 33 & 0.4 & $4 \cdot 8$ \\
\hline 12 & Hereditary elliptocytosis & 50 & 0.5 & $13 \cdot 1$ \\
\hline 13 & Sickle cell disease & 24 & 0.9 & $11 \cdot 2$ \\
\hline 14 & Sickle cell disease & 47 & $2 \cdot 4$ & $8 \cdot 6$ \\
\hline 15 & Auto-immune haemolytic anaemia & 0 & $3 \cdot 3$ & $8 \cdot 8$ \\
\hline 16 & Auto-immune haemolytic anaemia & 10 & $3 \cdot 1$ & 6.6 \\
\hline 17 & Auto-immune haemolytic anaemia & 23 & $2 \cdot 7$ & $5 \cdot 3$ \\
\hline 18 & Auto-immune haemolytic anaemia & 8 & 0.3 & $4 \cdot 6$ \\
\hline 19 & Auto-immune haemolytic anaemia & 85 & $3 \cdot 2$ & $10 \cdot 4$ \\
\hline 20 & Auto-immune haemolytic anaemia & 5 & 0.9 & $12 \cdot 7$ \\
\hline 21 & Auto-immune haemolytic anaemia & 0 & 0.7 & $9 \cdot 7$ \\
\hline 22 & Septicaemia & 31 & $1 \cdot 4$ & $7 \cdot 0$ \\
\hline 23 & Pyelo-nephritis, with uraemia & 27 & 0.4 & $5 \cdot 9$ \\
\hline 24 & Haemolytic anaemia of unknown cause & 8 & $1 \cdot 2$ & $11 \cdot 1$ \\
\hline 25 & Haemolytic anaemia of unknown cause & 0 & 0.7 & 5.6 \\
\hline
\end{tabular}


mg. $/ 100 \mathrm{ml}$. was found to have a normal red cell survival time (Table III). In those with a high level of haptoglobin the iron-deficiency anaemia was associated with such disorders as pyelitis, ulcerative colitis, hepatic cirrhosis, rheumatoid arthritis, or disseminated lupus erythematosus.

\section{TABLE III}

COMPARISON OF SERUM HAPTOGLOBIN LEVEL WITH RED CELL SURVIVAL MEASURED BY ${ }^{51}$ CR TECHNIQUE

\begin{tabular}{|c|c|c|c|}
\hline Case & Diagnosis & $\begin{array}{l}\text { Serum } \\
\text { Haptoglobin } \\
\text { (mg./100 ml.) }\end{array}$ & $\begin{array}{l}T_{\frac{1}{2}}{ }^{51} \mathrm{Cr} \\
\text { (days) }\end{array}$ \\
\hline 7 & Hereditary spherocytosis & 12 & $10(25 \cdot 5)^{1}$ \\
\hline 11 & Hereditary elliptocytosis & 33 & $22(32 \cdot 5)$ \\
\hline 12 & Hereditary elliptocytosis & 50 & $27(32 \cdot 5)$ \\
\hline 18 & Auto-immune haemolytic disease & 8 & $14(32 \cdot 5)$ \\
\hline 24 & $\begin{array}{l}\text { Haemolytic anaemia of } \\
\text { unknown cause }\end{array}$ & 8 & $25(32 \cdot 5)$ \\
\hline 25 & $\begin{array}{l}\text { Haemolytic anaemia of } \\
\text { unknown cause }\end{array}$ & 10 & $16(32 \cdot 5)$ \\
\hline 26 & Iron-deficiency anaemia & 28 & $25(25 \cdot 5)$ \\
\hline 27 & Idiopathic thrombocytopenia & 20 & $30(32 \cdot 5)$ \\
\hline 28 & $\begin{array}{l}\text { Haemoptysis (pulmonary } \\
\text { haemosiderosis) }\end{array}$ & 7 & $29(32 \cdot 5)$ \\
\hline 29 & Hodgkin's disease & 230 & $18(25 \cdot 2)$ \\
\hline 30 & Lymphosarcoma & 40 & $25(25 \cdot 5)$ \\
\hline 31 & Myeloid leukaemia & 72 & $14(25 \cdot 5)$ \\
\hline 32 & Myelofibrosis & 100 & $25(25 \cdot 5)$ \\
\hline 33 & Myelofibrosis & 105 & $28(32 \cdot 5)$ \\
\hline 34 & $\begin{array}{l}\text { Hypersplenism (hepatic } \\
\text { cirrhosis) }\end{array}$ & 102 & $28(32 \cdot 5)$ \\
\hline 35 & Hypersplenism (cause unknown) & 138 & $28(32 \cdot 5)$ \\
\hline 36 & Hypersplenism (cause unknown) & 33 & $16(32.5)$ \\
\hline 37 & Sideroblastic anaemia & 108 & $30(32 \cdot 5)$ \\
\hline 38 & Sideroblastic anaemia & 40 & $21(32 \cdot 5)$ \\
\hline 39 & Infective hepatitis & 0 & $28(32 \cdot 5)$ \\
\hline 40 & Carcinomatosis & 50 & $32(32 \cdot 5)$ \\
\hline 41 & Hammon-Rich syndrome & 145 & $33(32 \cdot 5)$ \\
\hline
\end{tabular}

${ }^{1}$ Figures in brackets are mean normal $\mathrm{T} \frac{1}{2}$ for the method used in each case.

RECENT HAEMORRHAGE The levels in these 27 cases covered the whole range from 0 to over $250 \mathrm{mg}$./ $100 \mathrm{ml}$. Those with haemorrhage into the tissuesovarian cyst, ectopic gestation, haemoptysis, thrombocytopenic purpura, cerebral haemorrhage, fractured femur-all had haptoglobin levels below $20 \mathrm{mg} . / 100 \mathrm{ml}$. Cases 27 and 28, with thrombocytopenic purpura and haemoptysis due to idiopathic pulmonary haemosiderosis respectively, had normal red cell survival times. The patient with the level of over $250 \mathrm{mg}$. $/ 100 \mathrm{ml}$. had an infected haematoma.

RETICULOSIS Of these 20 cases only one had a serum haptoglobin level below $40 \mathrm{mg}$. $/ 100 \mathrm{ml}$. This patient showed no evidence of haemolytic disease or haemorrhage into the tissues. All three patients with high levels had Hodgkin's disease. Cases 29 and 31 , who had levels of 230 and $72 \mathrm{mg}$. $/ 100 \mathrm{ml}$. respectively, had clinical and haematological evidence of haemolytic anaemia confirmed by reduced red cell survival times (Table III). In both cases of myelofibrosis, haptoglobin levels were within the normal range, which was in keeping with their normal red cell survival times.

MISCELLANEOUS ANAEMIAS Of the three cases with 'hypersplenism', two (cases 34 and 35) had normal haptoglobin levels, while the third (case 36) had a level of $33 \mathrm{mg} . / 100 \mathrm{ml}$. suggesting a haemolytic element in the anaemia. The red cell survival studies confirmed these observations, being normal in the two former cases and decreased in the one with the low level of haptoglobin. Both patients with aplastic anaemia had haptoglobin levels within the normal range. One patient with sideroblastic anaemia (case 37) showed a normal level of haptoglobin and normal red cell survival time, while the other (case 38) had a low level of haptoglobin and reduced red cell survival time (Table III).

OTHER DISORDERS The 44 cases in this group had levels ranging from 22 to over $250 \mathrm{mg}$. $/ 100 \mathrm{ml}$. Both patients with levels below $40 \mathrm{mg} . / 100 \mathrm{ml}$. had infective hepatitis. Case 39 had an unconjugated serum bilirubin level of $1.6 \mathrm{mg} . / 100 \mathrm{ml}$, reticulocytosis, no anaemia, and a red cell survival time within normal limits. The other patient had a moderate anaemia (haemoglobin $10 \cdot 2 \mathrm{~g} . / 100 \mathrm{ml}$.) with reticulocytosis and a small amount of unconjugated bilirubin in the serum but she underwent a rapid spontaneous remission before it was possible to estimate the red cell survival time. A further patient with this condition had a serum haptoglobin level of over $250 \mathrm{mg} . / 100 \mathrm{ml}$. High levels were also observed in another four patients of this group who had either a pyogenic abscess, acute bronchitis, or rheumatic fever.

\section{DISCUSSION}

The clinical value of any biochemical estimation depends upon the frequency of levels occurring outside the normal range in a particular group of disorders and upon the absence of such abnormal values in other conditions. We have found the level of serum haptoglobin to be subnormal in about $80 \%$ of cases with hereditary haemolytic disease, acquired haemolytic anaemia, or megaloblastic anaemia, but some of those whose haptoglobin level was within the normal range had evidence of increased haemolysis. Furthermore, a patient with Hodgkin's disease and another with myeloid leukaemia had normal levels of haptoglobin coincident with haemolytic anaemia. A normal haptoglobin level therefore does not exclude the possibility of haemolytic anaemia, especially when it occurs in patients 
who have conditions which are likely to give rise to abnormally high levels.

Apart from patients with known haemolytic disease or megaloblastic anaemia, in which there is also an increased rate of haemolysis, subnormal levels of haptoglobin were sometimes found in other disorders. In those with either hypersplenism or sideroblastic anaemia low levels correlated with reduced red cell survival. Several of the patients in whom the recent haemorrhage was into the tissues had absent or reduced levels of haptoglobin. It has previously been suggested that the mechanism causing these low levels may be similar to that which occurs with haemolysis (Richardson, Glick, Bates, and Shinton, 1963), the haemoglobin-haptoglobin complex in this instance being formed from haemoglobin which has entered the plasma following organization of blood clot. Reduced levels in hepatobiliary jaundice is a well recognized feature, but it is possible that in some cases it may be the result of increased haemolysis, as decreased red cell survival has been demonstrated by Pitcher and Williams (1963) in patients with hepatitis. Two of our cases with this condition showed haematological evidence of increased haemolysis but the red cell survival time in one of them was found to be normal. Williams et al. (1961) could find no correlation between serum haptoglobin and red cell survival times in patients with hepatitis but neither is there evidence that low levels are due to decreased synthesis (Owen et al., 1964). The patients who had iron-deficiency anaemia or lymphosarcoma and had low levels of serum haptoglobin showed no evidence to suggest that these were a consequence of release of haemoglobin into the plasma from any cause and so it is probable that these were extreme examples of the normal range.
Red cell survival studies using radio-active isotop@ techniques are probably the most accurate method. of assessing whether anaemia is due to increase $\bar{\phi}$ haemolysis or not, but they are time-consuming. procedures which require special equipment an take several weeks to complete. On the other hand $\frac{\bar{s}}{2}$ serum haptoglobin can be estimated in any hospita laboratory.

We wish to express our thanks to the laboratory staff, blood donors, and Bell Green old age pensioners wheे allowed us to examine samples of their blood; Dr. We Weiner of the Birmingham Regional Transfusion Services and Mr. H. Pluylaar for technical assistance.

\section{REFERENCES}

Allison, A. C., Blumberg, B. S., and Rees, Mrs. ap (1958). Naturg (Lond.), 181, 824.

Borglin, N. E., and Nyman, M. (1961). Scand. J. clin. Lab. Invest., 13. 107.

Brus, I., and Lewis, S. M. (1959). Brit. J. Haemat., 5, 348.

Dacie, J. V., and Lewis, S. M. (1963). Practical Haematology, 3rd ec. Churchill, London.

Iványi, J., Şochman, J., and Iványi, P. (1961). Acta haemat. (Basel), 25 98.

Jayle, M. F., and Boussier, G. (1955). Expos. ann. Biochim. méd., $1 \vec{\bigotimes}$ 157.

Mollison, P. L. (1961). Clin. Sci., 21, 21.

Neale, F. C., Aber, G. M., and Northam, B. E. (1958). J. clin. Pathe 11, 206.

Nosslin, B. F., and Nyman, M. (1958). Lancet, 1, 1000.

Nyman, M. (1959). Scand. J. clin. Lab. Invest., 11, suppl. 39.

Owen, J. A., Better, F. C., and Hoban, J. (1960). J. clin. Path., 13, 16

—, Mackay, I. R., and Got, C. (1959). Brit. med. J., 1, 1454. Padanyi, R., and Smith, H. (1961). Clin. Sci., 21, 189. Smith, R., Padanyi, R., and Martin, J. (1964). Ibid., 26, 1.

Pitcher, C. S., and Williams, R. (1963). Clin. Sci., 24, 239.

Polonovski, M., and Jayle, M. F. (1939). Bull. Soc. Chim. biol. (Parisł $21,66$.

Richardson, R. W., Glick, S., Bates, A., and Shinton, N. K. (1963 Lancet, 1, 608.

Smithies, O. (1955). Biochem. J., 61, 629.

Veall, N., and Vetter, H. (1958). Radioisotope Techniques in Clinica Research and Diagnosis. Butterworth, London.

Williams, R., Speyer, B. E., and Billing, B. H. (1961). Gut, 2, 297. 